\title{
Succession of sessile organisms on experimental plates immersed in Nabeta Bay, Izu Peninsula, Japan*. I. Algal succession
}

\author{
Tetsu Hirata
}

Institute of Biological Sciences, University of Tsukuba, Sakura-mura, 305 Ibaraki, Japan

\begin{abstract}
Algal succession over ca 3 yr was studied by suspending concrete plates at depths of 1.0 , 2.5, 4.0 and $5.5 \mathrm{~m}$ in Nabeta Bay, Shimoda, Pacific coast of Japan. A total of 17 species of macroalgae appeared during colonization. The process of algal succession was divided into 4 stages by dendrogram analysis: Stage 1 lacks macroalgae; Stage 2 has early colonizers; Stage 3 has a mixture of early, middle and late colonizers; Stage 4 has only late colonizers. Mainly green and red algae and the brown alga Colpomenia sinuosa appeared as early colonizers within 6 mo of immersion at Stage 2 , and then at Stage 3 the red alga Pterocladia capillacea and the green alga Codium adhaerens appeared as dominant species 10 or 13 mo after immersion. The pattern of transition of algae differed with depth. At depths of 1.0 and $2.5 \mathrm{~m}$, the kelp Eisenia bicyclis finally dominated, and early colonizers disappeared completely. At depths of 4.0 and $5.5 \mathrm{~m}$, E. bicyclis decreased in coverage or disappeared, giving way to a mixture of early (green algae U/va pertusa and Codium adhaerens), middle (red alga Gelidium amansi) and late colonizers (Eisenia bicyclis). In the period from 13 to 37 mo after immersion, the communities at the 3 upper depths advanced from Stage 3 to Stage 4 , while the community at the lowest depth returned from Stage 3 to Stage 1 and Stage 2. The number of species 37 mo after immersion was low at all depths. This seems to be due to inhibition of recruitment and growth of macroalgae through shading by $E$. bicyclis at depths of 1.0 and $2.5 \mathrm{~m}$, and through overgrowth of colonial animals at depths of 4.0 and $5.5 \mathrm{~m}$.
\end{abstract}

\section{INTRODUCTION}

Many studies on the succession of organisms colonizing hard substrates have been carried out because the sessile nature of these organisms makes observations and manipulation easy, their turnover rates are high, and their community development is rapid. It has been shown that the community structure of sessile organisms is influenced by several factors such as desiccation (Dayton 1971), waves and scouring by storm (Kitching 1937), exposure to wave action (Hoshiai 1965), shading (Kain 1969), log damage (Dayton 1971), sedimentation (McDougall 1943), grazing (Bakus 1966), herbivory (Randall 1961), predation (Stephenson \& Seales 1960), and overgrowth (Hoshiai 1959, 1960, 1965). Margalef (1968) and Odum (1969) suggest that, in stable environments, community attributes such as species composition, metabolism and succes-

- Contributions from the Shimoda Marine Research Center, No. 465

(c) Inter-Research/Printed in F. R. Germany sion reach a mature stage dominated by $K$-selected species (species with slow development, relatively high competitive ability, late reproduction, large body size and low metabolic rates). However, this remains controversial (Drury \& Nisbet 1973, Horn 1974, Connell \& Slatyer 1977). Studies on the changes of various community attributes in natural environments, e.g. intertidal rocky shores (Yamagami \& Mishima 1974, Niell 1979) and streams (Hannan \& Dorris 1970, Fisher et al. 1982) have not always shown the predicted mature state of community development expected by Margalef (1968) and Odum (1969).

Intertidal and stream environments are unstable because they are always exposed to frequent wave action or continuous water movement. Therefore, I studied the succession of sessile organisms in the subtidal zone which is considered stable compared with the intertidal zone. By suspending experimental plates, the changes through community development of species replacement, community structure, community metabolism, community biomass and commun- 
ity maturity were investigated for the purpose of testing the hypothesis of Margalef (1968) and Odum (1969), and clarifying the general characteristics in the community development of sessile organisms.

In this article, species replacement of algae on experimental plates and changes in species number during community development are described as the first report of a series of studies. The process of species replacement and pattern of changes in the number of species are discussed in relation to ecological and physiological characteristics of algal species observed.

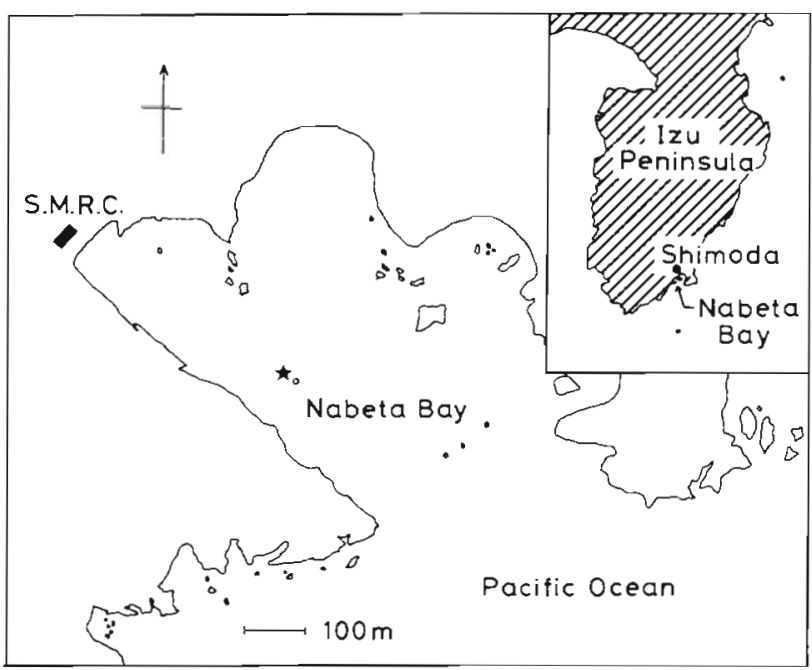

Fig. 1. Map showing study site ( $\star$ ) in Nabeta Bay, where experimental plates were immersed. S.M.R.C.: Shimoda Marine Research Center of University of Tsukuba
The process of community development observed is analyzed by dendrogram analysis, and features and transitional patterns of stages are examined. Lastly, some considerations were made on the interactions among algae and invertebrates during community development.

\section{MATERIALS AND METHODS}

The study site was in Nabeta Bay adjacent to Shimoda Bay at the southern end of the Izu Peninsula, Japan $\left(34^{\circ} 39^{\prime} 40^{\prime \prime} \mathrm{N}\right.$; $\left.139^{\circ} 56^{\prime} 35^{\prime \prime} \mathrm{E}\right)$. The site has a water depth of $6.0 \mathrm{~m}$ at lowest low tide and is located ca $400 \mathrm{~m}$ from Shimoda Marine Research Center (S.M.R.C.) of the University of Tsukuba where various observations and measurements were carried out (Fig. 1). Surface water temperatures in Nabeta Bay varied between $13.6^{\circ} \mathrm{C}$ (February) and $24.8^{\circ} \mathrm{C}$ (August) during the observation period. Surface salinities varied little, ranging from $32.6 \%$ in July to $34.2 \%$ in January.

Experimental concrete plates $(20 \mathrm{~cm} \times 20 \mathrm{~cm} \times$ $2 \mathrm{~cm}$ ) were suspended vertically at depths of $1.0,2.5$, 4.0 and $5.5 \mathrm{~m}$ below sea level (Fig. 2a). These depths are respectively designated as Depth A, B, C and D in the following description. A set of 4 plates was fixed with concrete cement to a polypropylene rope at the position corresponding to each depth (Fig. 2b). Then, 8 ropes each with 16 plates were tied, in the sea, to a galvanized pipe floated by several buoys so as to maintain the plates at the 4 fixed depths below the sea surface (Fig. 2a). This pipe was oriented northwest to

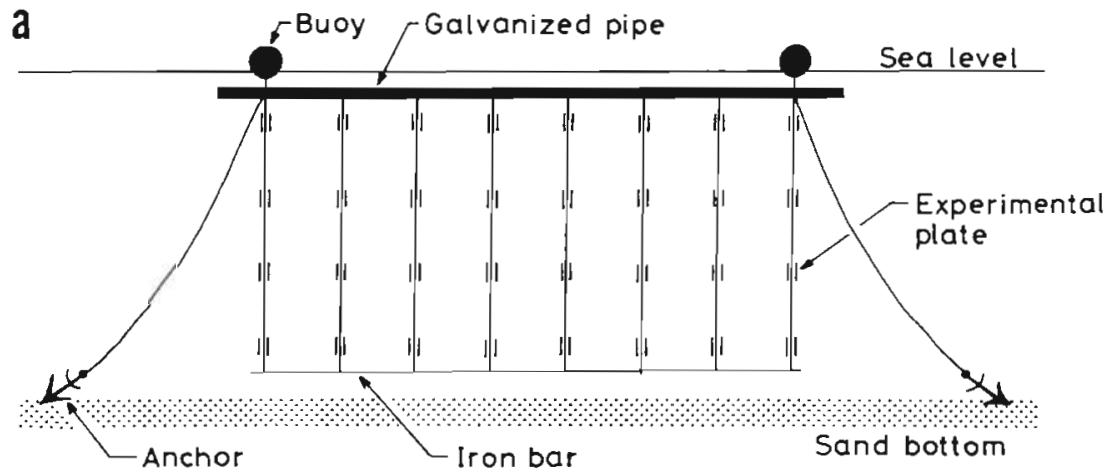

b

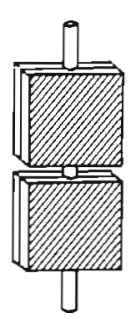

C

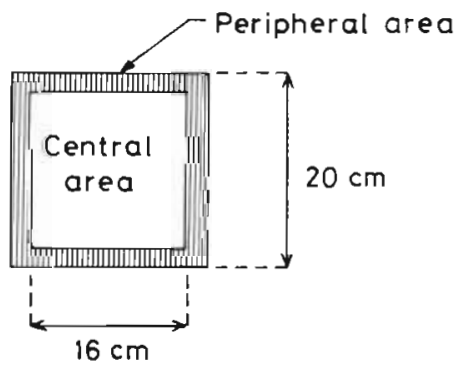

Fig. 2. (a) Diagram showing setting of experimental concrete plates in the sea. Eight ropes attached with plates are suspended from a galvanized pipe which is floated with buoys. Rope movement is limited by an iron bar. Four plates are fixed on each rope at each depth. This diagram is not to scale. (b) Diagram showing a set of 4 plates fixed to a rope. (c) Diagram showing the central area $(16 \mathrm{~cm} \times 16 \mathrm{~cm})$ of a plate, within which algae were examined for the calculation of percent cover 
southeast and held with several anchors to avoid the action of waves or swells, especially during typhoons in summer (Fig. 2a). A round iron bar was attached to the bottom ends of the ropes to avoid mutual contact of plates (Fig. 2a). The distance between vertical ropes was $70 \mathrm{~cm}$.

Setting of experimental plates was on 9 July 1974 , and sampling of plates was carried out 4 times in the first year (23 Aug to 2 Sep and 8 to 17 Nov 1974, 10 to $18 \mathrm{Jan}$ and 1 to 13 May 1975) and then 3 times in the late summers of subsequent years (9 to 15 Aug 1975, 6 to 23 Sep 1976,7 to 18 Aug 1977). In the following, the immersion period from setting out plates until each sampling time is represented by the approximate number of elapsed months, i.e. 2, 4, 6, 10, 13, 26 and $37 \mathrm{mo}$. A total of 112 plates were detached from the ropes for investigation. One rope with 16 plates was left in place to investigate further biotic changes.

On each sampling occasion, a set of 4 plates at Depth D was first detached from the rope and raised carefully, so as not to damage the organisms on the plates. The plates were carefully detached from the set with a hammer and screwdriver. They were transported to the laboratory at S.M.R.C., and kept in a running seawater tank until observation and measurement. At each sampling, metabolic rates of samples were first measured as soon as possible to investigate community metabolism. The plates were then photographed in color and the positions of sessile organisms on the plates were sketched briefly to estimate their coverage $(\%)$. All the organisms on one half of each plate were stripped off with a hammer and paint scraper, and were used for the determination of chlorophyll $a$, organic carbon, organic nitrogen, dry mass, ash dry mass, and ash-free dry mass. All the organisms on the other half of the plate were preserved in a $70 \%$ ethanol solution for identification. The plates removed from Depths C, B and A were treated in the same manner as described above. Three of 4 plates at each sampling were used for the above-stated observation and measurement, but in some cases only 2 plates were used. The remaining plate was used for identification of species. The results of studies on community metabolism and biomass will be reported in other papers.

As shown in Fig. 2c, the coverages of algal species in the central area $(16 \mathrm{~cm} \times 16 \mathrm{~cm})$ of plates were estimated by analysis of photographs. The peripheral area was excluded from counting because of a possible edge effect caused by sessile organisms or possible damage occurring during the experiment. The photographs were projected onto $1 \mathrm{~cm} \times 1 \mathrm{~cm}$ graph paper, and the coverage of each species was calculated by counting the number of squares occupied by the attachment sites of algae.

\section{RESULTS}

\section{Species composition and percent cover}

Macroalgae were not found on any of the plates immersed for up to 2 mo. Though articulated and nonarticulated coralline algae of the family Corallinaceae were found on all plates immersed longer than 2 mo, they are not included in the present study because of difficulty in discriminating their presence or absence accurately in the photographic analysis. During the period from 4 to 37 mo after immersion, a total of 17 species of algae were observed (Table 1). The changes in mean cover $(\%)$ of these 17 species over time are summarized in Table 1 . The time of appearance of each species and changes of its percent cover during community development are described below for each phylum.

\section{Chlorophyta}

Cladophora wrightiana, Ulva pertusa, Codium adhaerens, Codium fragile and Codium latum were early colonizers, all having recruited by 4 mo after immersion. C. wrightiana was a fugitive, not being found again after appearing at Depths A and B after 4 and 6 mo. Four mo after immersion, $U$. pertusa showed the highest percent cover at all depths; higher at Depths $A$ and $B$ than at $C$ and $D$. It was also highest in frequency, having recruited on all plates at Depths $A$, $B$ and $C$ and 1 of 3 plates at Depth D. Subsequently it declined gradually in cover until it disappeared almost completely from the plates; 13 mo after immersion it was found only at Depth D and was absent at all depths 26 mo after immersion. It appeared again at Depths C and D only, 37 mo after immersion.

The mossy alga Codium adhaerens recruited 4 mo after immersion at Depths $A$ and $B$ and 6 mo after immersion at Depths $C$ and $D$. Coverage reached a maximum 10 mo after immersion at all depths except Depth C. Cover had decreased at $13 \mathrm{mo}$, and this species was not found again on any plate except for a single reappearance at Depth $C$ after 37 mo.

Codium fragile and C. latum are taller algae, becoming large at maturity. They first appeared 4 or 6 mo after immersion and were found more frequently at Depths $A$ and $B$ until 13 mo after immersion. These 2 species often occurred outside the central area of plate. They reached a maximum size in the late spring 10 mo after immersion or in the late summer 13 mo after immersion. However percent cover was low because of the small size of their holdfasts. None of then were present 26 and 37 mo after immersion.

The remaining species, Chaetomorpha spiralis, was a fugitive, being found transiently during the experimental period. 
Table 1. Changes in the mean percent cover of algae observed in the central area $(16 \mathrm{~cm} \times 16 \mathrm{~cm})$ of experimental plates at 4 depths: A, $1.0 \mathrm{~m} ; \mathrm{B}, 2.5 \mathrm{~m} ; \mathrm{C}, 4.0 \mathrm{~m} ; \mathrm{D}, 5.5 \mathrm{~m}$. P: occurrence in the peripheral area of the plate

\begin{tabular}{|c|c|c|c|c|c|c|c|c|c|c|c|c|c|c|c|c|c|c|c|c|c|c|c|c|}
\hline \multirow[t]{3}{*}{ Species } & \multicolumn{24}{|c|}{ Immersion penod } \\
\hline & \multicolumn{4}{|c|}{$4 \mathrm{mo}$} & \multicolumn{4}{|c|}{$6 \mathrm{mo}$} & \multicolumn{4}{|c|}{$10 \mathrm{mo}$} & \multicolumn{4}{|c|}{$13 \mathrm{mo}$} & \multicolumn{4}{|c|}{$26 \mathrm{mo}$} & \multicolumn{4}{|c|}{$37 \mathrm{mo}$} \\
\hline & A & $\mathrm{B}$ & $\mathrm{C}$ & $\mathrm{D}$ & A & B & $\mathrm{C}$ & $\mathrm{D}$ & A & $B$ & $\mathrm{C}$ & $\mathrm{D}$ & A & B & C & $\mathrm{D}$ & A & $\mathrm{B}$ & C & $\mathrm{D}$ & A & $\mathrm{B}$ & $\mathrm{C}$ & $\mathrm{D}$ \\
\hline \multicolumn{25}{|l|}{ CHLOROPHYTA } \\
\hline Cladophora wrightiana & 1.8 & 0.2 & 0 & 0 & 5.3 & 1.7 & 0 & 0 & 0 & 0 & 0 & 0 & 0 & 0 & 0 & 0 & 0 & 0 & 0 & 0 & 0 & 0 & 0 & 0 \\
\hline Ulva pertusa & 3.1 & 4.4 & 1.8 & 0.9 & 2.5 & 1.7 & 1.6 & 0.1 & 0.3 & $\mathrm{P}$ & $\mathrm{p}$ & 0.1 & 0 & 0 & 0 & 0.4 & 0 & 0 & 0 & 0 & 0 & 0 & 0.1 & 0.1 \\
\hline Codium adhaerens & 2.1 & 2.7 & 0 & 0 & 5.1 & 6.6 & 3.8 & 3.3 & 11.91 & 19.7 & 1.6 & 6.3 & 0.7 & $\mathrm{P}$ & 3.1 & 2.2 & 0 & 0 & 0 & 0 & 0 & 0 & 0.5 & 0 \\
\hline Codium fragile & 0 & 0.7 & 0 & 0 & 0.7 & $\mathrm{P}$ & 0.4 & $\mathrm{P}$ & $\mathrm{P}$ & $\mathrm{P}$ & 0 & 0 & $\mathrm{P}$ & $P$ & 0 & 0 & 0 & 0 & 0 & 0 & 0 & 0 & 0 & 0 \\
\hline Codium latum & 0 & 0 & 0.4 & 0 & 0 & $\mathrm{p}$ & 0 & 0 & $\mathrm{P}$ & 0.9 & 0 & 0 & 1.3 & 1.0 & 0 & $\mathrm{P}$ & 0 & 0 & 0 & 0 & 0 & 0 & 0 & 0 \\
\hline Chaetomorpha spiralis & 0 & 0 & 0 & 0 & 0 & $\mathrm{P}$ & 0 & 0 & 0 & 0 & 0 & 0 & 0 & 0 & 0 & 0 & 0.4 & 0 & 0 & 0 & 0 & 0 & 0 & 0 \\
\hline \multicolumn{25}{|l|}{ RHODOPHYTA } \\
\hline Pterocladia capillacea & 5.3 & 12.9 & 3.1 & 4.0 & 1.8 & 0.8 & 0.3 & 0.3 & 5.8 & 3.5 & 0.6 & 3.0 & 0.7 & 3.9 & 18.1 & 6.1 & 0.5 & 1.2 & 0 & 0 & 0 & 0 & 0 & 0 \\
\hline Grateloupia sparsa & 0 & 0.5 & 0 & 0 & 0.3 & 0 & $\mathrm{P}$ & 0 & 0 & 0 & 0 & 0 & 0 & 0 & 0 & 0 & 0 & 0 & 0 & 0 & 0 & 0 & 0 & 0 \\
\hline Gracilaria textorii & 0 & 0 & 0 & 0 & 0.4 & 0.5 & 0.9 & 0 & 1.7 & 1.2 & 0.6 & 2.1 & 0 & 0 & 0 & 0 & 0 & 0 & 0 & 0 & 0 & 0 & 0 & 0 \\
\hline Champia parvula & 0 & 0 & 0 & 0 & 0 & 0.1 & 0 & 0 & 0 & 0 & 0 & 0 & 0 & 0 & 0 & 0 & 0 & 0 & 0 & 0 & 0 & 0 & 0 & 0 \\
\hline Ceramium paniculatum & 0 & 0 & 0 & 0 & 0 & 0 & 11.5 & 3.9 & 0 & 0 & 0 & 0 & 0 & 0 & 0 & 0 & 0 & 0 & 0 & 0 & 0 & 0 & 0 & 0 \\
\hline Plocamium telfairiae & 0 & 0 & 0 & 0 & 0 & 4.3 & 7.8 & 0.9 & 0 & 0 & 0 & 0 & 0.7 & 0 & 0 & 0 & 0.5 & 0 & 0 & 0 & 0 & 0 & 0 & 0 \\
\hline Grateloupia livida & 0 & 0 & 0 & 0 & 0 & 0 & 0 & 0 & $\mathrm{P}$ & $\mathrm{P}$ & 0 & 0 & 0 & 0 & 0 & 0 & 0 & 0 & 0.4 & 0 & 0 & 0 & 0 & 0 \\
\hline Gelidium amansii & 0 & 0 & 0 & 0 & 0 & 0 & 0 & 0 & $\mathrm{P}$ & $\mathrm{P}$ & 0 & 0 & 0 & 0 & $\mathrm{P}$ & 3.9 & 0 & 0 & 0 & 0 & 0 & 0 & 0 & $\mathrm{P}$ \\
\hline \multicolumn{25}{|l|}{ PHAEOPHYTA } \\
\hline Colpomenia sinuosa & 4.0 & 5.9 & 2.0 & 0 & 23.7 & 2.7 & 0.1 & 3.9 & 2.7 & $\mathrm{p}$ & $P$ & 0.3 & 0 & 0 & 0 & 0 & 0 & 0 & 0 & 0 & 0 & 0 & 0 & 0 \\
\hline Padina arborescens & 0 & 0 & 0 & 0 & 0 & 0 & 1.4 & 0 & 0 & $\mathrm{p}$ & 0 & 0 & 0 & 0 & 0 & 0 & 1.2 & 1.0 & 3.5 & 0 & $\mathrm{P}$ & 4.3 & 0 & 0 \\
\hline Eisenia bicyclis & 0 & 0 & 0 & 0 & 0 & 0 & 0 & 0.5 & 0 & 0 & 0 & 1.0 & 0 & 0 & 3.8 & 1.4 & 4.6 & 2.7 & 3.3 & 0 & 11.2 & 6.9 & 1.8 & $\mathrm{P}$ \\
\hline
\end{tabular}

Rhodophyta

Pterocladia capillacea and Grateloupia sparsa appeared as early colonizers 4 mo after immersion. The former species showed continuous occurrence, but the latter was a fugitive and not found during the period from 10 to 37 mo after immersion.

At 6 mo after immersion, Gracilaria textorii, Champia parvula and Ceramium paniculatum first appeared as early colonizers; $G$. textorii was found 6 to $10 \mathrm{mo}$ after immersion, and the others were fugitive appearing only at 6 mo after immersion. Their percent cover was low except for one appearance of a small filamentous C. paniculatum at Depth $C$ after 6 mo. The occurrence of these 3 species was restricted to the period from 6 to $10 \mathrm{mo}$ after immersion, so that they and Grateloupia sparsa are considered to be absent in summer.

Unlike the above-mentioned 4 species, Pterocladia capillacea, Plocamium telfairiae and Grateloupia livida were found in summer. They were first found on the plates immersed for 4,6 and 10 mo respectively. $P$. capillacea was continuously found 4 to $26 \mathrm{mo}$ after immersion at Depths $A$ and $B$ and 4 to 13 mo after immersion at Depths C and D. P. telfairiae was found 13 and 26 mo after immersion at Depth A. G. Livida was a fugitive, but was able to colonize even more than a year after the start of immersion since it first appeared 6 mo after immersion at Depth C. It is not clear whether the other 2 species survived as perennials or whether they had newly recruited 13 to 26 mo after immersion.

Gelidium amansii appeared transiently 10 or 13 mo after immersion. It also appeared on one Depth D plate immersed for $37 \mathrm{mo}$; no other species of red algae were found 37 mo after immersion. $G$. amansii can survive during the summer like the 3 species mentioned above, but it differs from them in that it shows later recruitment in succession.

\section{Phaeophyta}

Colpomenia sinuosa was an early colonizer, being found on the plates immersed for 4 mo at Depths $A, B$ and $C$ and a little later, on plates immersed for 6 mo, at Depth $D$. It was subsequently found at up to $10 \mathrm{mo}$ after immersion, and more abundantly at shallower depths. But it was not found on any plate in late summer during the period from 13 to 37 mo after immersion.

Padina arborescens grows larger than the previous species. It was occasionally found on plates immersed for 6 or 10 mo but not found on any plate immersed for $13 \mathrm{mo}$. It was found on only one plate at each of Depths $A$ to $C 26$ mo after immersion. It was also found on only one plate at each of Depths A and B 37 mo after immersion. This species was never found at Depth $D$.

Eisenia bicyclis grows much larger with its broad blades, long stipe and large holdfast. This species 
appeared earlier at greater depths: it was first found on plates of Depths A and B immersed for $26 \mathrm{mo}$, on plates of Depth $C$ immersed for $13 \mathrm{mo}$ and on plates of Depth D immersed for 6 mo. Recruitment occurred in the period from 13 to 26 mo after immersion at Depths A and B. The values of cover at Depths A and B increased with time to reach 11.2 or $6.9 \%$ respectively, 37 mo after immersion. On the other hand, the pattern of change in cover with time at Depths $C$ and D was reversed: at Depth $\mathrm{C}$ the cover decreased to $1.8 \%$ 37 mo after immersion, and at Depth D it was totally absent 26 mo after immersion. Nevertheless, one young individual of this species appeared again on one Depth D plate immersed for 37 mo.

\section{Changes in the number of species}

Temporal changes in the number of species are shown in Fig. 3. To confirm statistically the trend of its changes along the lapse of time, Spearman's rank correlation coefficients of the number of species on time were obtained for 3 sample periods which were arbitrarily assigned from the pattern of changes. Algal colonization proceeded rapidly after submerging experimental plates, and the number of species increased rapidly to reach a maximum approximately 6 mo after immersion (Fig. 3). Spearman's rank correlation coefficients were significantly positive during

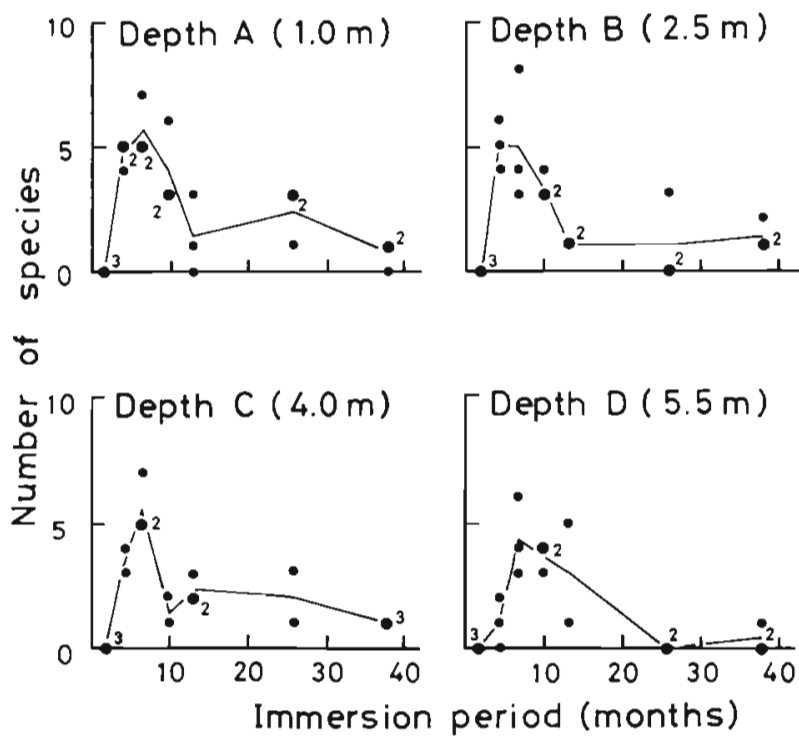

Fig. 3. Changes in the number of species in the central areas $(16 \mathrm{~cm} \times 16 \mathrm{~cm})$ of plates during community development at 4 depths. Curves show average number of species present per plate. Small solid circle represents a measurement for an individual plate; large solid circle represents 2 or 3 samples having the same number of species: numbers near them indicate number of samples
Table 2. Spearman's rank correlation coefficients showing the tendency of changes in the number of species in the central area $(16 \mathrm{~cm} \times 16 \mathrm{~cm}$ ) of plates. Sample size (number of plates examined) is shown in parentheses. '- Highly significant ( $<0.01)_{i}{ }^{*}$ significant $(p<0.05)$; ns: not significant $(p>0.05)$

\begin{tabular}{|lcrr|}
\hline \multirow{2}{*}{ Depth } & \multicolumn{3}{c}{ Immersion period (mo) } \\
& $2-6$ & $6-13$ & $13-37$ \\
\hline A $(1.0 \mathrm{~m})$ & $0.897(9)^{*}$ & $-0.808(9)^{*}$ & $-0.197(9) \mathrm{ns}$ \\
B $(2.5 \mathrm{~m})$ & $0.673(9)^{*}$ & $-0.784(8)^{\circ}$ & $0.203(8) \mathrm{ns}$ \\
C $(4.0 \mathrm{~m})$ & $0.974(8)^{\circ}$ & $-0.650(8)^{\circ}$ & $-0.748(8)^{\circ}$ \\
D $(5.5 \mathrm{~m})$ & $0.908(9)^{\cdots}$ & $-0.221(8) \mathrm{ns}$ & $-0.538(7) \mathrm{ns}$ \\
\hline
\end{tabular}

the period from 2 to 6 mo after immersion at all depths (Table 2). In the period from 6 to 13 mo after immersion, there was a tendency for the number of species to decrease with a significant correlation at Depths A, B and $C$ (Fig. 3, Table 2). In the period from 13 to 37 mo after immersion, the number of species remained almost unchanged at Depths $A$ and $B$, and its values were equal to or below those at 10 mo after immersion (Fig. 3). At Depths C and D, the number of species showed a tendency to decrease during the 13 to 37 month period (Fig. 3). This decrease was significant at Depth C (Table 2). At Depth D, the number of species showed low values of zero or 1 except for one value after 13 mo immersion (Fig. 3).

\section{DISCUSSION}

\section{Community development and ecological and physiological characteristics of algae}

The process of algal colonization is influenced by various physical environmental factors as well as by ecological and physiological characteristics of algae such as their life histories, growth rates, tolerance for shading in germination or growth, growth forms, tissue robustness, and interactions with colonial animals.

Early developmental process

Most of the green algae observed were earlier colonizers. The fact that their presence was restricted to the first 13 mo after immersion indicates that they are ephemeral and have an annual life history. Among green algae, Ulva pertusa with its foliose form is well known as an early ephemeral colonizer (e.g. Haderlie 1968, Kawahara 1969, Kennelly 1983, Sousa 1984). It showed high coverage in the initial stage of community development, but in later stages its percent cover decreased (Table 1). Codium adhaerens, which appeared a little later, increased in percent cover 
(Table 1). The higher percent cover of $C$. adhaerens seems to be due to its peculiar morphological form which is different from that of Ulva pertusa. U. pertusa grows upward from the small holdfast and its body is flimsy and flexible, but $C$. adhaerens spreads like a moss and its body is more robust. Moreover, the holdfast of $U$. pertusa does not become large with growth. Therefore, the young individual of $U$. pertusa is likely to be overgrown by colonial animals such as ascidians and bryozoans, which frequently dominated plates in this study. On the other hand, a small, flexible alga such as Cladophora wrightiana disappeared soon after its appearance. This disappearance was thought to be caused by the overgrowth of colonial animals. Dayton (1971) observed that the growth of the plates of barnacles' shells weakens the holdfasts of non-encrusting algae. However, such dislodgement was not observed in this study. Barnacles were first colonizers having abundant recruits, and grew rapidly all over the plates immersed for up to $4 \mathrm{mo}$. The barnacle shells provided attachment sites for the non-encrusting algae. Two large-sized species of Codium also have holdfasts larger in size than $U$. pertusa, and became mature 10 or 13 mo after immersion, dominating the water column on plates with their large thalli. Strong survival abilities of Codium spp. may be due to their thicker and more robust tissues and ability to grow rapidly. Because of these characteristics, they would not have been overgrown by colonial animals.

The first time of appearance of red algae differs with species: Pterocladia capillacea and Grateloupia sparsa appeared $4 \mathrm{mo}$ after immersion as the earliest colonizers; Gracilaria textorii, Champia parvula, Ceramium paniculatum and Plocamium telfairiae $6 \mathrm{mo}$ after immersion; Grateloupia livida and Gelidium amansii 10 mo after immersion. Though their reproductive seasons are not known, the timing of first colonization suggests that they each have peculiar physiological characteristics for attachment or germination. The red algae can be classified into 2 groups from the pattern of their appearances. The first group includes the species which appeared within the first year after immersion. These species were unable to survive the next summer. The second group includes those species which could be observed in the late summer, 13 mo after immersion, but often appeared even after this time. The former species are considered to be ephemeral or annual. On the other hand, the second group species are not necessarily perennial, because of the possibility of repeating recruitment every year. Northcraft (1948) indicated that red algae generally appear later in the colonization process than green and brown algae, perhaps because red algae produce non-motile spores whereas green and brown algae produce motile ones.
The brown alga Colpomenia sinuosa is known to be an early colonizer (e.g. Wilson 1925, Kawahara 1962, Murray \& Littler 1978), and its appearance was restricted to the first 10 mo after immersion. Moreover it was never observed in late summer. It is also known that $C$. sinuosa is an annual species; it propagates from spring to summer and then dies in summer in this area (K. Matsue pers. comm.). Eisenia bicyclis and Padina arborescens were able to colonize in the first year after immersion, and were found earlier at greater depths. This suggests that low light intensity at greater depths is suitable for their attachment, germination, or subsequent growth. Light intensity-photosynthesis curves suggest that $E$. bicyclis is a shade-adapted alga (Yokohama 1977). Generally, it is known that the germination of spores of red and brown algae is not inhibited at low light intensity, and the growth of these algae is good in these conditions (Arasaki 1953). The appearance of several kelp species including $E$. bicyclis was observed on artificial or cleared natural substrata at depths of 5 to $35 \mathrm{~m}$ within the first year of fouling experiments (Itô 1959, Iwahashi 1968, Fager 1971, Foster 1975, Dayton et al. 1984, Reed \& Foster 1984). A condition of low light intensity seems necessary for their germination and growth. The absence of $E$. bicyclis until $13 \mathrm{mo}$ after immersion at Depths A and B may be due to the inhibiting effect of high light intensity (Table 1 ).

At 10 or 13 mo after immersion, large-sized Codium fragile and $C$. latum dominated the water column at Depths A and B, but not at Depths C and D, where young individuals of $E$. bicyclis predominated. The large-sized Codium species seem unable to grow successfully at greater depths. This suggests that their growth is inhibited by $E$. bicyclis because the latter absorbs light near plates. Padina arborescens appeared transiently at Depths B and C in the first year after immersion. Light conditions at these depths would be suitable for the recruitment and growth of this alga. However, it was not always observed during the first year after immersion. The sporadic occurrence of this species may have been caused by overgrowth of colonial animals before reaching its mature size. When it was observed, it was always found on only one of the plates at each depth. This suggests that its recruitment is also essentially poor.

\section{Later developmental process}

At Depths A and B, after the decline of Ulva pertusa and several other green algae, large-sized Codium spp. occupied space from spring to late summer in the first year after immersion. Next, the perennial kelp Eisenia bicyclis appeared and finally dominated avail- 
able space (Table 1). At Depths $C$ and D, no clear dominant species was observed (Table 1).

Eisenia bicyclis was observed from the middle to late stage of community development. This may be because: it has a body consisting of shade-adapted blades; it has a robust stipe and holdfast; it forms a canopy which ensures its escape from shading; and it has a perennial life history with considerable longevity. The longevity of this species is known to be $>5 \mathrm{yr}$, from the growth rings on the stipe (Maegawa \& Kida 1984). These characteristics also made it possible to dominate finally both in area covered and in the water column near the plates at Depths A and B.

On the other hand, Eisenia bicyclis decreased in percent cover or disappeared entirely at Depths $C$ and $\mathrm{D}$ in the late stage of community development. Early colonizers, U7va pertusa and Codium adhaerens, and a middle colonizer appearing later in the first year after immersion, Gelidium amansiu, appeared again at Depths C and D 37 mo after immersion (Table 1). This reappearance indicates that such communities return to an early stage of community development. The pattern of this return at Depth $\mathrm{D}$ was different from that at Depth C. In Depth D samples, one young individual of $E$. bicyclis was observed 37 mo after immersion, but not found 26 mo after immersion (Table 1). Furthermore, $U$. pertusa and $G$. amansii existed simultaneously at Depth D 37 mo after immersion (Table 1). This indicates that a recovery from a secondary early stage to a later stage of community development occurred during the period from 26 to 37 mo after immersion.

The decrease in cover or disappearance of Eisenia bicyclis at Depths C and D mentioned above may have been caused mainly by sand scouring due to wave action. The removal of other algae by sand scouring is probably the cause for a return to the early stage of community development. There is the additional possibility that this decrease in cover or disappearance was also caused by contact of plates with the sand bottom due to the change of sea level with the tide or by the action of waves. Even at extreme low tides in May and December, the lower edges of the deepest sets of plates were about $30 \mathrm{~cm}$ off the sand bottom, since this study site is $6 \mathrm{~m}$ deep and the deepest sets of plates are maintained $5.5 \mathrm{~m}$ below the sea surface as already mentioned. Therefore, there seems little possibility that contact of plates with the bottom occurred at the low tide. On the other hand, while this study site is ordinarily calm with waves less than about $30 \mathrm{~cm}$ in height throughout the year, in stormy weather waves of 1 to $2 \mathrm{~m}$ in height were observed. Therefore, the deepest sets of plates might have come in contact with the sand bottom in some unfavorable conditions.

\section{Pattern of changes in the number of species}

Patterns of changes in the number of species during the period from 13 to $37 \mathrm{mo}$ after immersion are summarized as follows. At Depths $A$ and B, number of species remained almost unchanged during the period from 13 to 37 mo after immersion, ranging from zero to 3 species (Fig. 3, Table 2). This suggests that the dominant Eisenia bicyclis made the survival of other algae impossible through shading. At Depths $C$ and D, there was a decrease in the number of species after immersion for 13 mo (Fig. 3, Table 2). Most Depth D samples immersed for 13 to 37 mo had no algal species, being dominated mainly by the acorn barnacle Balanus trigonus. The surface structure of the community dominated by Balanus is not as rough as those at Depths $\mathrm{A}$ and $\mathrm{B}$ dominated by the massive bivalve Crassostrea nippona. The flat surface structure would make it easy for colonial ascidians or bryozoans to
Fig. 4. Dendrogram constructed from Horn's similarity coefficients based on the mean percent cover of algae in the central area $(16 \mathrm{~cm} \times 16 \mathrm{~cm})$ of a plate at each immersion period and depth. Major clusters are indicated by numbers and sub-clusters by the letters. Samples are indicated at right by months and their immersed depth (e.g. 2A indicates the sample immersed for 2 mo at Depth A). See text for further explanation

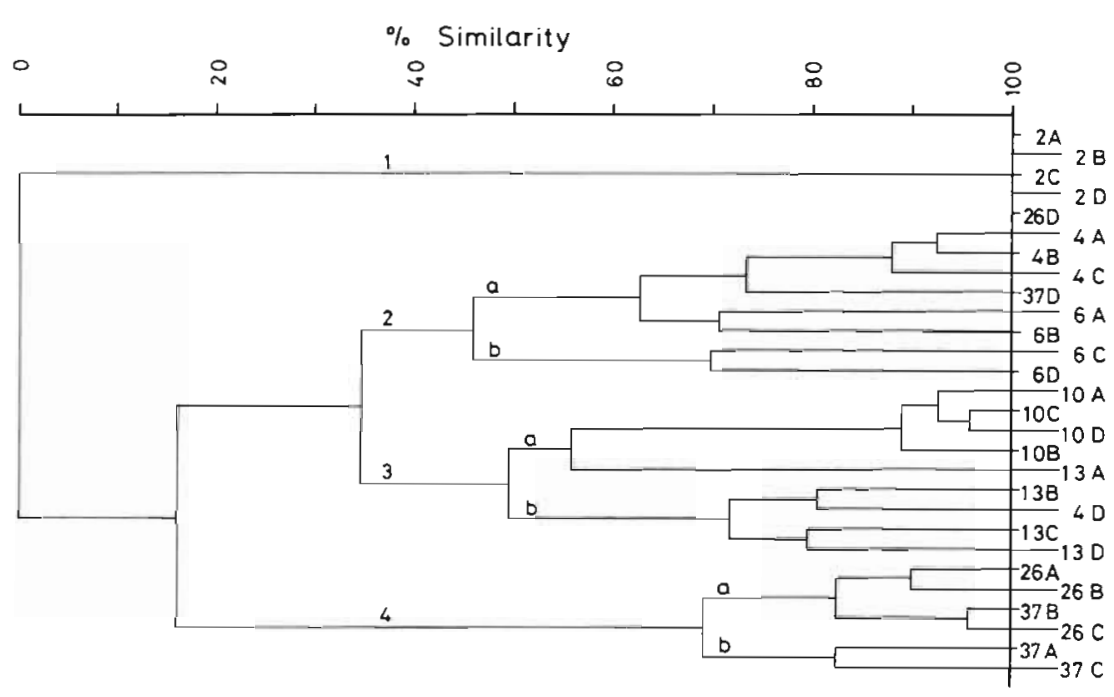


spread by asexual reproduction. The recruitment of algae is probably inhibited by the overgrowth of colonial animals. The dominant organisms in the later samples at Depths C and D were the colonial ascidian Diplosoma mitsukurii and the bryozoans Watersipora subovoidea and Amathia distans. The number of species at Depths A and B decreased similarly to zero or one 37 mo after immersion, but the process leading to this state differed from that at Depths $C$ and $D$. That is, the increase in the number of algae may have been inhibited by the shading of $E$. bicyclis at Depths $\mathrm{A}$ and $B$ and by the overgrowth of colonial animals at Depths C and D.

\section{Stages in community development inferred from dendrogram analysis}

To discriminate successive stages of community development, the samples were subjected to cluster analysis using Horn's coefficient of similarity (Horn 1966), based on Shannon-Wiener information theory and the weighted group average method. The data used for this analysis were the mean percent cover of algal species in the central area of plates. The results of the analysis are shown as a dendrogram in Fig. 4 , in which 4 major clusters can be discriminated. The level of percentage similarity for this division was arbitrarily determined to be between 34.7 and $45.9 \%$ (Fig. 4). The samples were generally clustered with time, but Depth D samples immersed for 26 and 37 mo were similar to earlier ones immersed for 2 or 4 mo, suggesting a return to an early stage of development. The 26 mo samples showed more similarity to younger ones than to the 37 mo ones. On the other hand, Depth A to $\mathrm{C}$ samples immersed for 26 and $37 \mathrm{mo}$, which were more similar to each other, were evidently different from earlier samples immersed for 2 to $13 \mathrm{mo}$. They showed development to a more heterogeneous stage in community structure. Of these, the 37 mo Depth A and $C$ samples were most heterogeneous, and are considered to be more developed or mature communities.

In the following discussion, the 4 major clusters (Fig. 4) were regarded as 4 stages in community development. Based on the results of this cluster analysis, the samples can be arranged according to depth and time and partitioned into the 4 stages shown in Fig. 5.

As seen in this diagram, Depth $\mathrm{A}$ to $\mathrm{C}$ communities shifted successively from Stage 1 to Stages 2, 3 and 4 with time. On the other hand, Depth $D$ community showed a different pattern of development (Fig. 5). It by-passed Stage 2 in the initial process of community development, and shifted directly from Stage 1 to the more developed Stage 3. But it returned transitionally

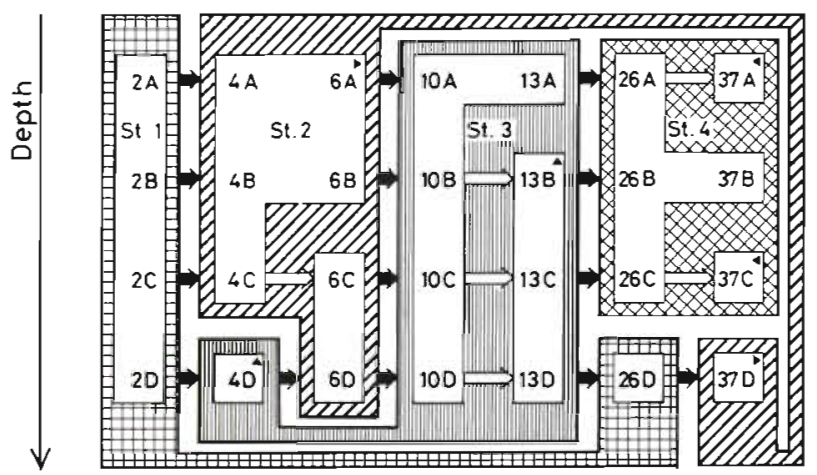

Time

Fig. 5. Diagram showing the processes of community development at 4 depths, inferred from the results of dendrogram analysis shown in Fig. 4. Four kinds of hatched areas represent 4 developmental stages divided by the dendrogram analysis. Areas without hatching represent sub-clusters. The triangles on the right-hand corner of some boxes represent the same sub-cluster. Black arrows indicate transition from one developmental stage to the next. White апrows indicate transition from one sub-cluster to the other. Code as in Fig. 4

to Stage 2 after 6 mo immersion. It advanced again to Stage 3 after 10 and 13 mo immersion, when the A to C communities were also all at the same stage. The $D$ community showed a return to Stage 1 after 26 mo immersion and a further recovery to Stage 2 after $37 \mathrm{mo}$. This irregular sequence of stages, clearly different from that of $\mathrm{A}$ to $\mathrm{C}$ communities, was probably caused mainly by disturbance such as scouring of bottom sand.

\section{Features of developmental stages}

Features of the 4 stages distinguished in this study are summarized in Table 3 .

In Stage 1, no macroalgae visible with the naked eye were observed, but the existence of some algae is inferred from the presence of chlorophyll a in $90 \%$ acetone extracts of samples or by the production of oxygen when exposed to light. This suggests the presence of macroalgae at the germination stage or of microalgae such as diatoms or filamentous brown algae (e.g. Ectocarpus spp.). Bacteria, diatoms, Ectocarpus spp. and hydroids have been observed as a sheet-like film in the earliest stage of succession on marine substrata (e.g. ZoBell \& Allen 1935, Coe \& Allen 1937, Itô 1959, Kawahara 1962, Kazihara 1964. Fager 1971, Foster 1975). This stage is, therefore, characterized by a sheet-like film consisting of the organisms mentioned above.

In Stage 2, Colpomenia sinuosa and Pterocladia capillacea were dominants. Though the mean percent 
Table 3. Developmental stages derived from the dendrogram analysis shown in Fig. 4. Each stage is characterized by the species which are dominant and subdominant in mean percent cover. The degree of domination is ranked by the average of the 2 ranks of mean percent cover and frequency of appearance. + l less than $0.1 \%$. Numerator: number of samples in which algal species were observed. Denominator: total number of samples

\begin{tabular}{|c|c|c|c|c|}
\hline Stage & Dominant or subdominant species & $\begin{array}{l}\text { Mean percent } \\
\text { cover }\end{array}$ & $\begin{array}{l}\text { Appearance } \\
\text { frequency }\end{array}$ & $\begin{array}{c}\text { Rank of } \\
\text { domination }\end{array}$ \\
\hline 1 & No macroalgae & & & \\
\hline 2 & $\begin{array}{l}\text { Colpomenia sinuosa } \\
\text { Pterocladia capillacea } \\
\text { Ulva pertusa } \\
\text { Codium adhaerens } \\
\text { Ceramium paniculatum } \\
\text { Plocamium telfairiae } \\
\text { Cladophora wrightiana }\end{array}$ & $\begin{array}{l}5.3 \\
3.1 \\
1.9 \\
3.0 \\
1.9 \\
1.6 \\
1.1\end{array}$ & $\begin{array}{l}7 / 8 \\
7 / 8 \\
8 / 8 \\
6 / 8 \\
2 / 8 \\
3 / 8 \\
4 / 8\end{array}$ & $\begin{array}{l}1 \\
2 \\
3 \\
4 \\
5 \\
6 \\
7\end{array}$ \\
\hline 3 & $\begin{array}{l}\text { Pterocladia capillacea } \\
\text { Codium adhaerens } \\
\text { Gracilaria textoni } \\
\text { Eisenia bicyclis } \\
\text { Ulva pertusa } \\
\text { Codium latum } \\
\text { Gelidium amansï } \\
\text { Plocamium telfairiae }\end{array}$ & $\begin{array}{l}5.1 \\
5.1 \\
0.6 \\
0.7 \\
0.2 \\
0.4 \\
0.4 \\
+\end{array}$ & $\begin{array}{l}9 / 9 \\
7 / 9 \\
4 / 9 \\
3 / 9 \\
4 / 9 \\
3 / 9 \\
1 / 9 \\
1 / 9\end{array}$ & $\begin{array}{l}1 \\
2 \\
3 \\
4 \\
5 \\
6 \\
7 \\
8\end{array}$ \\
\hline 4 & $\begin{array}{l}\text { Eisenia bicyclis } \\
\text { Padina arborescens } \\
\text { Pterocladia capillacea } \\
\text { Codium adhaerens }\end{array}$ & $\begin{array}{l}5.1 \\
1.7 \\
0.3 \\
+\end{array}$ & $\begin{array}{l}6 / 6 \\
4 / 6 \\
2 / 6 \\
1 / 6\end{array}$ & $\begin{array}{l}1 \\
2 \\
3 \\
4\end{array}$ \\
\hline
\end{tabular}

cover of Ulva pertusa and Codium adhaerens was low, the 2 species existed in many or all samples. This stage is characterized by early colonizers.

In Stage 3, Pterocladia capillacea and Codium adhaerens were dominants. Gracilaria textori, Eisenia bicyclis, Ulva pertusa, Codium latum and Gelidium amansii occupied subordinate positions. This stage is characterized by a mixture of early, middle and late colonizers.

In Stage 4, Eisenia bicyclis was always dominant. Padina arborescens was observed as a subdominant. This stage is characterized by late colonizers.

\section{Interactions among algae and invertebrates}

Fifteen algal species had appeared on the plates within 6 mo after immersion (Table 1). Of these, perennial and shade-adapted species of algae are considered to have outcompeted the ephemeral, annual and more sun-adapted species through interspecific competition for light. The algae surviving until the later stages of community development are considered to be species more tolerant of low light intensity. Eisenia bicyclis can be regarded as a representative of perennial and shade-adapted algae. The later recruitment of the remaining 2 species might be facilitated by low light intensity brought about by the early colonizers.
On the other hand, they may be regarded as tolerant species resistant to reduced light intensity during community development, if they had recruited simultaneously on plates with the early colonizers and then survived throughout community development. The first time of appearance of E. bicyclis differs with depth. It appeared first in the 1 st to 2 nd year after immersion at Depths $\mathrm{A}$ and B, later than at Depths C and $D$. This suggests that it was probably assisted by low light intensity brought about by resident algae. At Depths A and B 37 mo after immersion where E. bicyclis occurred as a dominant, no algae other than this species and Padina arborescens were present in spite of the existence of the free spaces created by the death and loss of Crassostrea nippona, Balanus trigonus, Megabalanus volcano and $M$. rosa (Table 1). At Depths $\mathrm{C}$ and $\mathrm{D}$ where colonial animals dominated, only 4 algal species were observed 37 mo after immersion (Table 1). This suggests that at Depths A and B the recruitment and growth of other algae is inhibited by E. bicyclis and at Depths C and D by the overgrowth of colonial animals. It has been suggested that space is a main limiting resource in the community development of sessile invertebrates, because interspecific competition among them through smothering has a great effect on the determination of community structure (Connell 1961, Dayton 1971, Emerson \& Zedler 1978, Dean \& Hurd 1980). Also in an algal community, space seems 
to be a limiting resource in some cases. But light, inducing a depth stratification in the algal community, seems to be a much more important limiting resource for the recruitment, germination and growth of algae than space, because interspecific competition among algae through shading has a great effect on the determination of the community structure.

Acknowledgements. I thank Dr. J. Mishima, Institute of Biological Sciences, University of Tsukuba, for suggesting this study as well as for constant guidance during the course of the work. Thanks are also due to Dr. L. R. Pomeroy, Institute of Ecology, University of Georgia, Dr. S. Nishiwaki, College of Medical Technology and Nursing. University of Tsukuba, and Dr. Y. Yokohama, Shimoda Marine Research Center of University of Tsukuba for their valuable comments on the manuscript. I am much indebted to some other staff members of Shimoda Marine Research Center for their assistance during the course of this study.

\section{LITERATURE CITED}

Arasaki, S. (1953). An experimental note on the influence of light on the development of spores of algae. Bull. Jap. Soc. scient. Fish. 19: 466-470

Bakus, G. J. (1966). Some relationships of fishes to benthic organisms on coral reefs. Nature, Lond. 210: 280-284

Coe, W. R., Allen, W. E. (1937). Growth of sedentary marine organisms on experimental blocks and plates for nine successive years at the pier of the Scripps Institution of Oceanography. Bull. Scripps Instn Oceanogr. tech. Ser. 4 : 101-136

Connell, J. H. (1961). The influence of interspecific competition and other factors on the distribution of the barnacle Chthamalus stellatus. Ecology 42: 710-723

Connell, J. H., Slatyer, R. O. (1977). Mechanisms of succession in natural communities and their role in community stability and organization. Am. Nat. 111: 1119-1144

Dayton, P. K. (1971). Competition, disturbance, and community organization: the provision and subsequent utilization of space in a rocky intertidal community. Ecol. Monogr 41: 351-389

Dayton, P. K., Currie, V., Gerrodette, T., Keller, B. D., Rosenthal, R., Tresca, D. V. (1984). Patch dynamics and stability of some California kelp communities. Ecol. Monogr. 54: 253-289

Dean, T. A., Hurd, L. E. (1980). Development in an estuarine fouling community: the influence of early colonists on later arrivals. Oecologia (Berl.) 46: 295-301

Drury, W. H., Nisbet, I. C. T. (1973). Succession. J. Arnold Arbor. 54: 331-368

Emerson, S. E., Zedler, J. B. (1978). Recolonization of intertidal algae: an experimental study. Mar. Biol. 44: 315-324

Fager, E. W. (1971). Pattern in the development of a marine community. Limnol. Oceanogr. 16: 241-253

Fisher, S. G., Gray, L. J., Grimm, N. B., Busch, D. E. (1982). Temporal succession in a desert stream ecosystem following flash flooding. Ecology 52: 93-110

Foster, M. S. (1975). Algal succession in a Macrocystis pyrfera forest. Mar. Biol. 32: 313-329

Haderlie, E. C. (1968). Marine fouling organisms in Monterey Harbor. Veliger 10: 327-341
Hannan, H. H., Dorris, T. C. (1970). Succession of a macrophyte community in a constant temperature river. Limnol. Oceanogr. 15: 442-453

Horn, H. S. (1966). Measurement of 'overlap' in comparative ecological studies. Am. Nat. 100: 419-424

Horn, H. S. (1974). The ecology of secondary succession. Ann. Rev. Ecol. Syst. 5: 25-37

Hoshiai, T. (1959). Synecological study on intertidal communities. II. On the interrelation between the Hijikia fusiforme zone and the Mytilus edulis zone. Bull. Mar. Biol. Stn Asamushi, Tohoku Univ. 9: 123-126

Hoshiai, T. (1960). Synecological study on intertidal communities. III. An analysis of interrelation among sedentary organisms on the artificially denuded rock surface. Bull. Mar. Biol. Stn Asamushi, Tohoku Univ. 10: 49-56

Hoshiai, T. (1965). Synecological study on intertidal communities. VI. A synecological study on the intertidal zonation of the Asamushi coastal area with special reference to its re-formation. Bull. Mar. Biol. Stn Asamushi, Tohoku Univ. 12: 93-126

Itô, T. (1959). Marine sedentary communities with special reference to the succession in the Inland Sea of Japan. Bull. Mar. Biol. Stn Asamushi, Tohoku Univ. 9: 161-165

Iwahashi, Y. (1968). Ecological studies on Eisenia and Ecklonia in the coast of Izu Peninsula. I. On the growth of Ecklonia cava Kjellman. Bull. Shizuoka Pref. Fish. Exp. Stn 1: $27-31$

Kain, J. M. (1969). The biology of Laminaria hyperborea. $\mathrm{V}$. Comparison with early stages of competitors. J. mar. biol. Ass. U.K. 49: 455-473

Kawahara, T. (1962). Studies on the marine fouling communities. I. Development of a fouling community. Rep. Fac. Fish., Pref. Univ. Mie 4: 27 41

Kawahara, T. (1969). Studies on the marine fouling communities. IV. Differences in the constitution of fouling communities according to localities. a. Nagasaki Harbor. Rep. Fac. Fish., Pref. Univ. Mie 6: 109-125

Kazihara, T. (1964). Ecological studies on marine fouling animals. Bull. Fac. Fish. Nagasaki Univ. 16: 1-138

Kennelly, S. J. (1983). An experimental approach to the study of factors affecting algal colonization in a sublittoral kelp forest. J. exp. mar. Biol. Ecol. 68: 257-276

Kitching, J. A. (1937). Studies in sublittoral ecology. II. Recolonization at the upper margin of the sublittoral region; with a note on the denudation of Laminaria forest by storms. J. Ecol. 25: 482-495

Maegawa, M., Kida, W. (1984). Ecological studies on Eisenia bicyclis and Ecklonia cava communities. III. Seasonal changes in allometric relation of Eisenia frond. Rep. Fac. Fish., Pref. Univ. Mie 11: 189-198

Margalef, R. (1968). Perspectives in ecological theory. University of Chicago Press, Chicago

McDougall, K. D. (1943). Sessile marine invertebrates of Beaufort, North Carolina. Ecol. Monogr. 13: 321-374

Murray, S. N., Littler, M. M. (1978). Patterns of algal succession in a perturbed marine intertidal community. J. Phycol. 14: 506-512

Niell, F. X. (1979). Structure and succession in rocky algal communities of a temperate intertidal system. J. exp. mar. Biol. Ecol. 36: 185-200

Northcraft, R. D. (1948). Marine algal colonization on the Monterey Peninsula, California. Am. J. Bot. 35: 396-404

Odum, E. P. (1969). The strategy of ecosystem development. Science, N.Y. 164: 262-270

Randall, J. E. (1961). Overgrazing of algae by herbivorous marine fishes. Ecology 42: 812

Reed, D. C., Foster, M. S. (1984). The effects of canopy shad- 
ing on algal recruitment and growth in a giant kelp forest. Ecology 65: 937-948

Sousa, W. P. (1984). Intertidal mosaics: patch size, propagule availability, and spatially variable patterns of succession. Ecology 65: 1918-1935

Stephenson, W., Searles, R. B. (1960). Experimental studies on the ecology of intertidal environments at Heron Islands. 1. Exclusion of fish from beach rock. Aust. J. mar. Freshwat. Res. 11: 241-267

Wilson, O. T. (1925). Some experimental observations of marine algal successions. Ecology 6: 303-311

Yamagami, A., Mishima, J. (1974). The ecological studies on the intertidal rockyshore communities in respect to their metabolic activities. II. The successional changes in the community metabolism. Sci. Rep. Tokyo Kyoiku Daig. Sec. B. 15: 281-291

Yokohama, Y. (1977). Productivity of seaweeds. In: Hogetsu, K., Hatanaka, M., Hanaoka, T., Kawamura, T. (ed.) JIBP SYNTESIS, Vol. XIV, Productivity of biocenoses in coastal regions of Japan. University of Tokyo Press, Tokyo, p. 119-127

Zobell, C. E., Allen, E. C. (1935). The significance of marine bacteria in the fouling of submerged surfaces. J. Bacteriol. 29: $239-251$

This article was submitted to the editor; it was accepted for printing on September 5, 1986 